\title{
Ribeirinhos em Resistência à Gestão Biocêntrica de Unidades de Conservação Pública e Privada no Pantanal
}

\author{
Riverine Peasants Resisting Bio-centric Management \\ of Public and Private Conservation Units in the \\ Pantanal Wetlands
}

\author{
Ana Maria de Souza Mello Bicalhoi \\ Universidade Federal do Rio de Janeiro \\ Rio de Janeiro, Brasil \\ Scott William Hoefle ${ }^{\mathrm{ii}}$ \\ Universidade Federal do Rio de Janeiro \\ Rio de Janeiro, Brasil \\ Ana Paula Correia de Araújo \\ Universidade Federal de Mato Grosso do Sul \\ Campo Grande, Brasil
}

\begin{abstract}
Resumo: Este trabalho analisa o conflito socioambiental no qual a população ribeirinha é ameaçada por unidades de conservação ambiental pública e privadas no norte de Mato Grosso do Sul e limite com Mato Grosso. O Parque Nacional do Pantanal Matogrossense e reservas particulares de patrimônio natural - RPPN - articulam-se em uma forte rede de conservação biocêntrica e ameaçam a população tradicional ribeirinha gerando conflito. O objetivo é analisar e avaliar o conflito, quanto a questões fundiárias e a restrições que são impostas pelas unidades de conservação sobre a população limitando o modo de vida de legado histórico. Ribeirinhos resistem e alianças extra local são formadas visando a permanência no lugar. Abordagem teórica baseia-se na História Ambiental Radical e na Ecologia Política Crítica, questionando injustiça social em ações ambientais discriminatórias de populações rurais vulneráveis.
\end{abstract}

Palavras chaves: Conflito Socioambiental; População Tradicional Ribeirinha; Ecologia Política Crítica; Justiça Ambiental; Pantanal.

\footnotetext{
' Professora Titular - Programa de Pós-Graduação em Geografia. anabicalho@ppgg.igeo.ufrj.br. https://orcid.org/0000-0003-1352-7170

ii Professor Titular - Programa de Pós-Graduação em Geografia. scotthoefle@acd.ufrj.br. https://orcid. org/0000-0001-5454-0377

iii Professora Associada - Faculdade de Engenharias, Arquitetura e Urbanismo e Geografia. Programa de Pós-Graduação em Estudos Fronteiriços. ana.araujo@ufms.br. https://orcid.org/0000-0002-39996373
} 
Abstract: This study analyzes socio-environmental conflict involving the riverine population situated along the state line between Mato Grosso do Sul and Mato Grosso States that is threatened by public and private nature reserves. The nature reserves are articulated in a powerful bio-centric conservation network embracing the Pantanal National Park and private reserves. The objective here is to analyze and evaluate conflict over land ownership rights and restrictions imposed by the conservation units which annul the livelihoods of a legally designated traditional population. Against this threat the riverine peasants mounted a resistance movement and built extra-local alliances with the objective of remaining in place. A theoretical framework based on Radical Environmental History and Critical Political Ecology is used to question environmental injustice concerning policies that discriminate against vulnerable rural populations.

Keywords: Socio-environmental Conflict; Traditional Tiverine Population; Critical Political Ecology; Environmental Justice; Pantanal Wetlands.

\section{Introdução}

Com base em perspectivas da História Ambiental Radical e da Ecologia Política Crítica, são questionadas aqui as imposições de unidades de conservação ambiental que discriminam os ribeirinhos históricos do rio Paraguai a noroeste do estado do Mato Grosso do Sul, limite com o estado de Mato Grosso e fronteira com a Bolívia. Uma região remota de difícil acesso exclusivamente por via fluvial, conhecida como região do Amolar, inclusa na subdivisão pantaneira do Pantanal do Paraguai. As unidades de conservação ambiental, com um discurso de incompatibilização da ocupação com a preservação da natureza, colocam em risco a permanência e a vida da população local constituída por pescadores camponeses. Isso posto, o objetivo central é analisar e avaliar o conflito entre unidades de conservação ambiental e ribeirinhos históricos, considerando, por um lado, restrições fundiárias e de recursos impostas sobre a população local limitando o modo de vida e, por outro lado, o processo de resistência e alianças constituídas para o reconhecimento de direitos territoriais.

O conflito socioambiental está no centro de interesse deste trabalho, cujos objetivos específicos são: a) analisar as origens e o desdobramento do conflito entre as unidades de conservação e a população ribeirinha; b) avaliar as mudanças no modo e qualidade de vida da população ribeirinha no cenário da transformação das fazendas tradicionais de gado bovino em unidades de conservação ambiental e c) compreender as alianças de instituições que se manifestam a favor dos ribeirinhos com fins de lhes viabilizar e garantir direitos, mediando o conflito e a permanência de vida da população na região.

Na história recente, a população passou por dois movimentos de resiliência e adaptação a situações externas fora de seu controle. Um decorrente de causas naturais com o represamento e elevação do nível do rio Paraguai em 1974, em função da "grande cheia" associada ao assoreamento do rio a jusante, inundando permanentemente amplas áreas. Um segundo momento, de natureza ambientalista e econômica, foi o da conversão de fazendas com grandes extensões de área inundada em unidades de conservação ambiental cuja gestão restringe o acesso da população a recursos básicos de seu modo de vida. 
Interesses fundiários e força política ambientalista tornam as questões desse segundo momento muito mais complexas e difíceis à população ribeirinha e expõem sua vulnerabilidade frente às unidades de conservação que se instalam na região. Se no momento da inundação permanente de extensas áreas se impunha a necessidade de adaptação do modo de vida a um ambiente mais aquático, agora, novas estratégias requerem, por um lado, o enfrentamento de forças opressoras de gestores ambientalistas e, por outro lado, a luta pelo reconhecimento de direitos e a busca por alianças com agentes externos de apoio social e humanitário.

A conversão da fazenda Caracará no Parque Nacional do Pantanal Mato-grossense (PARNA Pantanal) em 1981 com 135.581 hectares, estendendo a Reserva Biológica Caracará de 80.000 hectares de $1971^{1}$ (BRASIL, 1971, 1981), colocou a região em evidência, atraindo nas décadas seguintes, pela sua rica biodiversidade, investidores na formação de Reservas Particulares de Proteção Natural (RPPN), unidades de conservação propícias a compensações ambientais de setores empresariais.

Ambas as formas de unidades de conservação na região, governamental e não governamental, não reconhecem os direitos das populações tradicionais, os ribeirinhos históricos na região, como garantidos pela legislação brasileira ${ }^{2}$. Estes se veem cerceados em seu modo de vida, ameaçados no seu sustento e na sua expulsão da área onde vivem há muitas gerações. Conflito que é aqui retratado e analisado à luz de críticas a posturas e políticas biocêntricas na conservação ambiental, questionadas pelo quadro de injustiça ambiental gerado junto à população ribeirinha no extremo norte da sub-região do Paraguai, região do Amolar.

\section{Ecologia Política e Justiça Ambiental}

A defesa biocêntrica da natureza com raízes nas ciências biológicas vem tendo capilaridades em outras áreas do conhecimento influenciando um consenso do direito da natureza e das coisas - direito intrínseco à natureza em si e para além do valor humanista que é prevalente nas ciências sociais. Um argumento que adquire força e valor exclusivo, considerando a natureza como entidade à parte do ser humano, este identificado apenas como agente antrópico predador. É um raciocínio que, posto em exacerbação, desconsidera a interação sociedade-natureza e ignora questões sociais. A Ecologia Política, contrária ao biocentrismo ambiental, integra questões ambientais e humanistas, tendo em vista uma ecologia moral que concilia ao mesmo tempo natureza e justiça ambiental (GRIFFIN et al., 2019; PEET et al., 2011). Semelhantes são as críticas de historiadores ambientalistas críticos, que se opõem à visão binária do biocentrismo no histórico da criação de unidades de conservação (DOWIE, 2009; JACOBY, 2014).

Estudos críticos na História Ambiental Radical tem suas raízes nos trabalhos de Cronin (1983, 1991), Crosby (1986), Merchant (1992), Pepper (1996) e Wilson (1992), enquanto na Ecologia Política sobressaem os trabalhos de Blaikie e Brookfield (1986) na geografia, de Wolf (1982) na antropologia e de Redclift (1987) na sociologia. Ambas perspectivas se radicalizaram na primeira década do século XXI e convergiram a críticas ao escuso contexto ambientalista global - "guerra" geopolítica sobre recursos energéticos, violentos movimentos neocolonialistas e aumento de desigualdades sociais e regio- 
nais. Decisões políticas globais sobre emissão e reservas de carbono e compensações ambientais estão na base do debate crítico sobre unidades de conservação e práticas conservacionistas.

O enclausuramento da natureza em unidades de conservação e preservação ambiental excluindo a presença humana revive e copia uma história ambiental dos Estados Unidos de fins do século XIX e início do século XX, quando da criação de parques e florestas nacionais naquele país. Um dos ícones desse período, largamente citado junto aos propositores atuais do biocentrismo como exemplo a ser seguido, é o Yellowstone National Park. Apesar de ser consagrado como um marco para a defesa ambiental, pouco se divulga sobre os efeitos sociais desastrosos desse e de outros eventos no estabelecimento de unidades de conservação na história ambiental nos Estados Unidos.

Historiadores ambientais contemporâneos críticos desqualificam/desmitificam ícones americanos como o ambientalista Marsh, promulgador de políticas de reservas naturais protegidas e a criação dos parques de Yellowstone e do Grand Canyon. Agentes e reservas dessa história são reconhecidos, hoje, como detentores de falta de ética e de "limpeza" social nas paisagens destinadas à preservação ou associados a interesses escusos de elites da época (JACOBY, 2014). A difusão desse modelo para o mundo acompanhando o imperialismo europeu e norte-americano causou: a) cem anos de conflito entre agentes da conservação e a população nativa e colonos pobres, criminalizados, despossuídos de terras e bens, acompanhados de expulsão ou remoção e a comum realocação em locais sem condições à sua reprodução e modo de vida (DOWIE, 2009); b) "recriação" de uma natureza "prístina" a ser não só mantida pelos atributos ecológicos, mas para apreciação de beleza cênica - natureza a ser visitada - por indivíduos em lazer e com conforto da classe alta de regiões urbanas ricas (ADAMS; MULLIGAN, 2003; WILSON, 1992).

Dos tempos coloniais ao presente, a visão ocidental biocêntrica de uma "Natureza Essencial" sem a presença humana (populações rurais) imposta na ordem mundial é uma forma de criar reservas da natureza "destiladas" e livres de ações antrópicas. Populações são removidas de seus ancestrais territórios e seus sistemas produtivos são deformados, sem contraparte de adequações ou inovações de suporte e melhorias de vida com consequente degradação das condições sociais (DOWIE, 2009; JACOBY, 2014).

Críticos contemporâneos sustentam a necessária decolonização da natureza e apoiam práticas de uso sustentável como mais apropriadas (ADAMS; MULLIGAN, 2003). São contrários à ética elitista biocêntrica como também à visão reversa de negação de valores e processos ecológicos. Defendem a convergência, uma ordem que atenda a valores humanos e ecológicos e status moral (MERCHANT, 1992; PEPPER, 1996). Mesmo ponto de vista foi defendido por geógrafos reunidos em 2015 em Londres na International Conference of Historical Geographers, tendo como resultante das discussões o livro Moral Ecologies (GRIFFIN et al., 2019). Na Geografia Histórica, questões ambientais são fundamentadas na visão integradora sociedade-natureza.

Com raízes na Economia Política e na compreensão de processos de exclusão e marginalização de grupos sociais de baixa renda na economia capitalista, a Ecologia Política integra as questões sociais ao contexto da flexibilização espacial do capitalismo e da globalização-ambiente. Essa abordagem se insere no crescente debate sobre degradação 
ambiental, emissões de carbono e mudanças climáticas, incide e enfatiza uma visão macro, planetária, global, que em si oculta relações e interesses políticos e econômicos subjacentes ao discurso ambiental. Mitigação a mudanças climáticas através de compensações do mercado de troca de carbono entre países é um exemplo amplamente criticado na Ecologia Política por manter problemas na origem, ao mesmo tempo em que prega transferência de responsabilidades ambientais globais a outras regiões e países distantes do centro do problema em si (BUMPUS; LIVERMAN, 2011). Proposições "verdes" a atividades agrícolas, industriais e de serviços insustentáveis que ocultam a natureza destrutiva do capitalismo. Ao culpar e responsabilizar o aumento das emissões globais pelo desmatamento em países em desenvolvimento desvia-se a atenção do problema maior advindo da indústria e do estilo de vida pós-industrial, os grandes poluidores (HARVEY, 2014; PEET et al., 2011).

O colonialismo carbônico legitima o enclausuramento ou o cercamento da natureza e as disputas "verdes" perpetradas contra populações tribais e camponesas que não tendo como resistir são forçadas a sair das áreas demarcadas à conservação ambiental. Ação que tem eco em Marx, parte 6 de $O$ Capital, que descreve o cercamento dos campos na Escócia resultando na expulsão da terra de camponeses que são convertidas em ambientes para a caça de veados para o lazer de nobres ingleses. De forma similar, atualmente, elites metropolitanas fazem o mesmo em escala global tendo como fim o consumo da natureza (HOEFLE, 2019; BÜSCHER, FLETCHER, 2018; PEET et al., 2011).

Unidades de conservação ambiental são geralmente criadas em áreas marginais essencialmente rurais e as populações, já pobres, são as que arcam com o ônus da política ambiental, processo que Kelly-Reif e Wing (2016) reconhecem como exploração urbana do rural. Gestores ambientais de origem urbana pouco conhecem e desprezam o modo de vida e os problemas dessa população. Este é o cerne da discussão de (in)justiça ambiental com referência à implementação de políticas de conservação e criação de parques nacionais e reservas naturais com exclusão de populações.

Justiça social e justiça ambiental sempre foram importantes para a Ecologia Política embora não como conceitos tão explícitos como entre sociólogos e ativistas urbanos em países desenvolvidos. Através de métodos quantitativos e procedimentos jurídicos, pesquisadores urbanos mostram como em escala local grupos sociais discriminados são mais expostos a ameaças ambientais devido sua localização próxima de instalações poluentes e de alto risco ambiental em bairros pobres das cidades (ASCERALD, 2002; HOLIFIELD, 2015). Até os anos 2000 a Ecologia Política, por sua vez, envolvia geógrafos e antropólogos investigando em múltiplas escalas a vulnerabilidade ambiental e pobreza rural em países em desenvolvimento. Nas últimas duas décadas, presenciamos a convergência entre essas abordagens de forma que justiça ambiental passou a ser pesquisada, tanto por estudiosos urbano-industriais quanto estudiosos rurais em países desenvolvidos e em países em desenvolvimento (ASCERALD, 2010; HOLIFIELD, 2015).

Justiça ambiental é questão recorrente nos conflitos socioambientais em unidades de conservação no Brasil. Em vista do alto custo social imposto às populações residentes em áreas convertidas à preservação da natureza, a legislação brasileira tem procurado um equilíbrio entre as partes. Nesse sentido, sobressai como instrumento legal de proteção a populações tradicionais residentes em áreas de conservação natural o Decreto $n^{\circ}$ 
6.040 de 7 de fevereiro de 2007, que define e reconhece diretos territoriais de povos e comunidades tradicionais:

Povos e Comunidades Tradicionais: grupos culturalmente diferenciados e que se reconhecem como tais, que possuem formas próprias de organização social, que ocupam e usam territórios e recursos naturais como condição para sua reprodução cultural, social, religiosa, ancestral e econômica, utilizando conhecimentos, inovações e práticas gerados e transmitidos pela tradição (Brasil, Decreto $\mathrm{n}^{\circ} 6.040$ de 7/2/2007, Art 30, inciso I).

Territórios Tradicionais: os espaços necessários à reprodução cultural, social e econômica dos povos e comunidades tradicionais, sejam eles utilizados de forma permanente ou temporária (Brasil, Decreto n 6.040 de 7/2/2007, Art 3º, inciso II).

Todavia, grupos sociais residentes históricos, de baixa renda e com modos de vida próprios e culturalmente estabelecidos, são vulneráveis e têm sido violados e desrespeitados em seus direitos de permanecer e viver na terra quando da criação de unidades de conservação. Essa população com identidade e modo de vida interdependente da relação com a natureza local, tem sido constantemente ameaçada e expulsa ou, se mantida no local, sofre fortes restrições e involução de seus sistemas produtivos com precarização de sua qualidade de vida e comprometimento de sua reprodução social. A ênfase de gestores de unidades de conservação ambiental a uma visão biocêntrica e/ou a um discurso restrito que separa a sociedade humana de uma natureza intocável sem a presença humana, vista como perniciosa/comprometedora à resiliência de ecossistemas, tem sido a justificativa para a expulsão de grupos sociais históricos de seu lugar de vida/origem. Assim, se (re)produz violência e injustiça ambiental em solo brasileiro no discurso de defesa da natureza. Um dos exemplos é o embate e ameaças aos ribeirinhos do Pantanal, afetados pelas unidades de conservação, como tratado neste trabalho.

\section{Métodos}

A pesquisa foi desenvolvida com base em informações de trabalho de campo em 2015 em data de realização programada para coincidir com o dia da audiência pública do Ministério Público Federal de Corumbá a ocorrer na comunidade de Barra de São Lourenço, inclusa nas ações do movimento Expedição da Cidadania da Associação dos Juízes Federais do Brasil - AJUFE. A pauta da audiência foi sobre o conflito das unidades de conservação ambiental - PARNA Pantanal e RPPNs - com a população ribeirinha. Foi possível à equipe de pesquisadores participar como observadores dessa audiência pública do Ministério Público Federal que visava a mediação de conflitos entre gestores das unidades de conservação e os ribeirinhos face à não observância dos diretos das famílias residentes há gerações na região e que sofrem constantes pressões e ameaças de expulsão. 
Presenciou-se depoimentos dos diferentes atores, população local, agente do Instituto Chico Mendes de Conservação da Biodiversidade - ICMBio - na gestão do Parque Nacional do Pantanal Mato-grossense, gerentes e outros representantes das Reservas Particulares de Proteção Ambiental. O contexto de vida e falas dos ribeirinhos e seus contrários, filmadas, expõem a relação conflituosa e constituem fonte de informações. Selecionadas falas dos ribeirinhos durante a audiência foram registradas em vídeo para divulgação pública ${ }^{3}$.

Antecedendo à audiência, no percurso para Barra de São Lourenço, foram realizadas entrevistas e questionários semiabertos junto à população ribeirinha que vive nas margens do rio Paraguai, município de Corumbá, na já mencionada área conhecida como região do Amolar, com várias e extensas unidades de conservação. Região remota, de difícil acesso por longo e meandrado trajeto exclusivamente fluvial, sem adensamentos populacionais e com baixíssima densidade demográfica. A região faz fronteira com a Bolívia, onde há contiguidade de área protegida, a Área Natural de Manejo Sustentado de San Martin no país vizinho.

A observação participativa da audiência pública integrada ao método da investigação teve como propósito entender melhor o conflito pela práxis dos diferentes atores considerando a representação discursiva de cada grupo social em confronto. Permitiu, também, se inteirar sobre as alianças e o papel das redes de atores ali representadas expressando relações sociopolíticas externas integradas ao conflito local. Histórico e modo de vida foram obtidos através de inventários de campo usuais à pesquisa empírica na geografia com a população foco e direcionados às questões norteadoras da investigação. Para o alcance da complexidade do conflito socioecológico, teve-se, ainda, o suporte de ampla base bibliográfica, incluindo legislação específica concernente ao problema analisado.

Obteve-se no levantamento de campo informações sobre 34 famílias, distribuídas pelas comunidades da região, além de serem entrevistadas 15 mulheres ribeirinhas seguindo roteiro de perguntas específico e 5 trabalhadores de fazendas, de fazendas tradicionais e de uma fazenda, hoje, pertencente a um proprietário externo da região.

A população in locu contatada distribui-se em localidades com um agregado de poucas casas, locais nomeados de "comunidades"4. Considerando as localidades/comunidades, segundo a ECOA (2014a, 2014b, 2015), há um total de 64 famílias que se distribuem por: Barra de São Lourenço - 22 famílias -, Amolar - 4 famílias -, São Francisco e Paraguai-mirim - 38 famílias. A amostragem realizada corresponde a $53 \%$ das famílias da região.

Assuntos recorrentes dos levantamentos empíricos foram: pesca e uso de outros recursos naturais, sistemas agropecuários, produção para autoconsumo e articulação ao mercado, relações de trabalho, mobilidade espacial, estrutura familiar e qualidade de vida em geral. Questões que caracterizam o modo de vida local e que se fazem presentes no conflito socioambiental na região. Também foram ouvidos depoimentos de história oral de informantes chaves, residentes de longa data no local que vivenciaram as mudanças que deram origem à paisagem e dinâmica atual da vida na região. Informações que foram complementadas por consulta a bibliografia específica de estudos de base social sobre a área. Falas e informações qualitativas foram confirmadas por outros estudos e documentos oficiais e instrumentos legais pertinentes ao caso em foco. 
Conforme as matrizes teóricas, as informações foram analisadas segundo: a) a história ambiental radical procurando entender as raízes da população ao local e sua interação com a natureza através de suas histórias de vida e as pressões sofridas pelas unidades de conservação e b) a ecologia política crítica, suporte na análise das mudanças no sistema produtivo, restrições ao acesso a recursos básicos e das novas relações de poder do ambientalismo biocêntrico em choque com justiça socioambiental. Justiça que faz juz ao nexus da sustentabilidade, fundamentado na interação socioecológica pela intercessão de sistemas naturais e sistemas humanos que se interagem e se retroalimentam (FAO, 2014). Nexus inconteste aos objetivos sociais explícitos na Agenda 2030 da Organização das Nações Unidas nos quais se reforçam processos inclusivos de populações vulneráveis, realçando e associando a proteção e dignidade de grupos sociais marginais com a proteção de ecossistemas e de recursos naturais. O conflito socioambiental foi analisado buscando entender as raízes do problema e as visões e comportamento dos diferentes atores, a fim de contribuir no suporte das relações sociais e ambientais para um processo de conservação com justiça social.

\section{Cercamento e Cerceamento da Natureza pelas Unidades de Conservação}

\section{As unidades de conservação ambiental}

O Pantanal é um dos maiores conjuntos de terra sazonalmente alagada do mundo. Constitui-se de uma planície aluvial no alto da bacia do rio Paraguai, com grande carga de sedimentos anualmente depositados pelo ciclo de cheias e vazantes responsável pelas grandes extensões de alagados. Detém grande biodiversidade em si no contato da planície com o planalto que o circunda e na transição a outros ecossistemas, como o amazônico e o cerrado. Possui, ainda, beleza cênica de rios e montanhas circundantes e da flora e fauna exuberante. A ocupação humana, o ritmo da vida e das atividades acompanham a sazonalidade do regime e da dinâmica fluvial que modela a geomorfologia local caracterizada por áreas mais ou menos alagadas e inundáveis. O Pantanal não é um espaço homogêneo e os elementos naturais são considerados na sua diferenciação interna identificando sub-regiões. A regionalização de Silva e Abdon (1998), reconhecendo onze sub-regiões pantaneiras, é bastante utilizada e é a que nos referimos ao localizarmos a região do Amolar na sub-região do Pantanal do Paraguai.

O Pantanal do Paraguai é a sub-região pantaneira com as maiores extensões de áreas perenemente alagadas e períodos de inundações anuais mais longos que podem atingir até seis a oito meses e em grandes extensões. A maior incidência pedológica é de solos glei pouco húmicos, eutróficos, argila de atividade alta e solos aluviais nas margens dos rios, enquanto que em direção à serra do Amolar há ocorrência de vertisolos e solonetz-solodizados (VIEIRA et al., 2006, p. 53). Os rios se confundem em um emaranhado de meandros, braços de rios e ilhas. Há a presença de grandes baías e lagoas e grande diversidade da flora e fauna ${ }^{5}$. Nessa paisagem, com característica não muito favorável a atividades agrícolas, vivem os ribeirinhos, com um modo de vida interdependente da natureza, principalmente dos rios. A mesma natureza, contudo, atrai a criação de unidades de conservação ambiental, sendo os ribeirinhos afetados negativamente por elas, 
que os excluem e se abstêm de qualquer suporte devido e lhes impingem fortes restrições ao modo de vida.

Unidades de conservação ambiental têm sido implantadas nos estados de Mato Grosso e Mato Grosso do Sul; extensas áreas de preservação em espaços contínuos. O Parque Nacional do Pantanal Matogrossense (PARNA Pantanal), criado em 1981, localiza-se em Mato Grosso, município de Poconé, tendo no seu limite sul o Mato Grosso do Sul e ocupa uma área de 135.581 hectares (BRASIL, 1981). O PARNA Pantanal é circundado por grandes Reservas Particulares de Patrimônio Natural - RPPNs - interconectadas - Acurizal, Penha, Rumo ao Oeste, propriedades de uma mesma organização, a Fundação de Apoio à Vida nos Trópicos - ECOTROPICA. A pouca distância ao sul, encontra-se a RPPN Engenheiro Eliezer Batista criada em 2008, propriedade pertencente à empresa MMX Mineração e Metálicos S.A. que adquire ainda outras fazendas ${ }^{6}$. Associada ao Instituto Homem Pantaneiro - IHP, este se torna o gestor das áreas ligadas à MMX. Em 2009, as RPPNs da ECOTRÓPICA e do IHP, o PARNA Pantanal, a Fazenda Santa Teresa, o Instituto Acaia, e outras duas fazendas, formam a Rede de Proteção e Conservação da Serra do Amolar. Com atuação conjunta, a rede amplia seu poder de influência sobre setores ambientais regionais.

As reservas particulares atendem à Lei no 9.985 de 2000 de referência ao Sistema Nacional de Unidades de Conservação da Natureza (SNUC) e ao Decreto $\mathrm{n}^{\circ} 5.746$ de 2006 quanto a dispositivos referentes à RPPN (BRASIL, 2006). Entretanto, seus proprietários e gestores descumprem o Decreto $n^{\circ} 6.040$ de 2007, decreto este que reconhece direitos dos povos e comunidades tradicionais e seus territórios e que visa, segundo seu Anexo, em Objetivos Específicos, Art. $3^{\circ}$ inciso II, "solucionar e/ou minimizar os conflitos gerados pela implantação de Unidades de Conservação de Proteção Integral em territórios tradicionais e estimular a criação de Unidades de Conservação de Uso Sustentável" (BRASIL, 2007). Não tem havido compatibilidade das RPPNs aos diretos territoriais da população ribeirinha local gerando conflitos, por vezes, violentos e ameaçadores.

Agrava o conflito socioambiental o fato das RPPNs assumirem o papel preponderante de regulação e fiscalização do entorno e da zona de amortecimento em alianças ou assumindo o lugar de órgãos públicos. Consta do plano de manejo das reservas da ECOTROPICA, e nos parece uma atitude imprópria, estabelecer estratégias de interferência fora dos limites das reservas:

Considerando que o SNUC não prevê a existência legal da Zona Tampão de dez quilômetros ao redor da RPPN e levando em conta a intransferibilidade do poder de polícia para uma ONG, a definição da Zona de Entorno foi indicada como um instrumento estratégico para direcionar as atividades de conservação da Ecotrópica (ECOTRÓPICA, 2003, p. xiv).

Propositalmente, cria-se estrategicamente uma imprecisão no entendimento sobre o entorno e a jurisdição responsável ao caso específico, justificando uma atuação exacerbada da RPPN para além de sua competência e sem afinidade com a população da vizinhança em cumprimento ao Decreto n 6.040 de 2007. Assim sendo, o plano de manejo se contradiz quando propõe uma ação cooperativa com os atores locais e afirma, 
sem concretizar, que "sua estrutura prevê ações no entorno das Unidades visando à cooperação das populações vizinhas e a melhoria da sua qualidade de vida" (ECOTRÓPICA, 2003, p.xiv). É irônico ver esta afirmativa da própria instituição, uma vez que suas ações são exatamente opostas. A população ribeirinha se vê restringida em áreas para moradia, acesso à água potável, recursos extrativos essenciais e materiais para edificação de suas rústicas residências. O exercício de atividades produtivas básicas é limitado pela imposição de fortes restrições e barreiras nos rios e lagos à pesca artesanal, orquestradas não apenas por uma das RPPN, mas por todas elas articuladas entre si.

Questões sociais no entorno de limites e de zonas de amortecimento não são exclusivas do Pantanal. Intencionalmente ou não gestores ambientais mantém visão unilateralmente ecológica sem constrangimentos ou exacerbam os efeitos de borda. Ao observar que a legislação concernente à zona de amortecimento não elimina ocupações tradicionais e atividades, apenas as regula de forma a manter equilíbrio entre a ocupação e uso da terra e a preservação de ecossistemas. A não observância a essa relação gera conflitos e desconfianças entre as partes, como expõe Ferreira:

A zona de amortecimento é uma ferramenta ecológica, corroborada pelo direito, que somente atinge sua finalidade se estiver em consonância com a realidade local e com a dinâmica de uso e ocupação da terra. [...] frente à população, que repetidamente tem demonstrado entender que a zona tampão é uma extensão da UC, não raramente acusando os executores do SNUC de utilizá-la para aumentar, escusadamente, os limites da unidade (FERREIRA apud SILVA NETO, 2012, p. 2).

É dessa maneira como a população ribeirinha entende e se rebela às imposições das RPPNs. Uma visão que é reforçada com o agravo da associação das RPPNs a setores públicos, o ICMBio responsável e gestor do PARNA Pantanal e gestor regional do SNUC com função de regulador das unidades de conservação na região, além de órgãos de fiscalização ambiental. Essas alianças, ditas como parcerias, podem representar a subordinação de órgãos públicos ao controle de agentes particulares e não vice-versa.

Não estão longe da verdade, uma vez que o PARNA Pantanal associou-se às RPPNs e fazendas na Rede de Proteção e Conservação da Serra do Amolar e que, articulados entre si, seguem propostas conservacionistas em consonância com interesses específicos da rede (Quadro 1). Rede, esta, que envolve grandes empresários e tem apoio de organizações internacionais. Siqueira et al. (2018) têm informação que essa rede de unidades de conservação monitora e fiscaliza a área fora de seus limites em intervalos de 15 a 15 dias, além de intimidar os ribeirinhos proibindo a pesca em corixos e baías. Junto com o PARNA Pantanal a rede tem influência sobre uma área de 276.087 hectares. Fica difícil o diálogo da população tanto com as RPPNs quanto com o órgão federal que seria de intermediação e de controle da gestão ambiental na região. Esse cenário de cooptação do setor público pelo privado torna os ribeirinhos, já com precárias condições de vida, ainda muito mais vulneráveis e sem representatividade para a defesa de permanência e de seu modo de vida, em cumprimento ao ensejo de proteção de populações e comunidades tradicionais. 


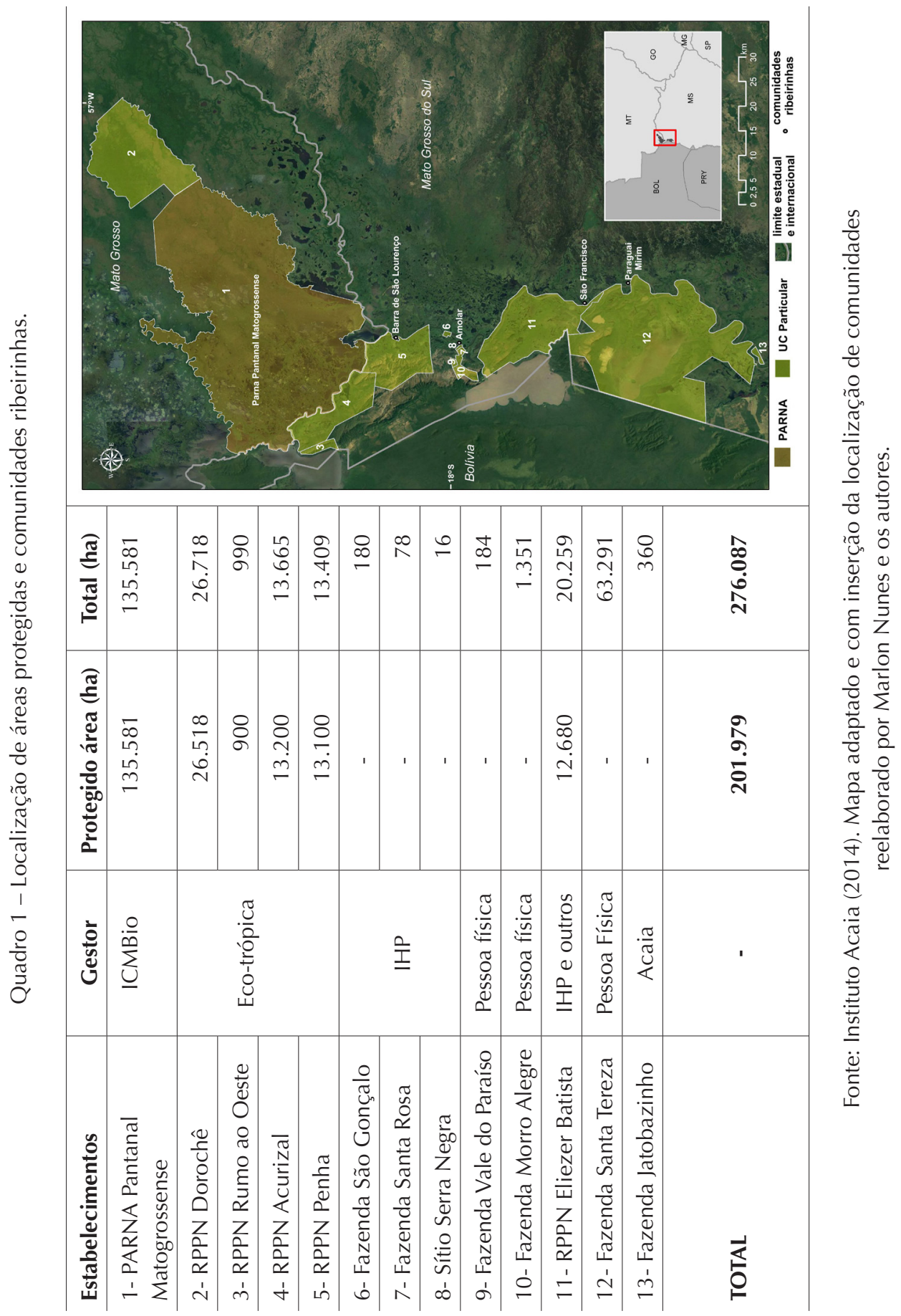

Espaço Aberto, PPGG - UFRJ, Rio de Janeiro, V. 10, N.2, p. 205-235, 2020 
Localmente, a serra do Amolar delimita a planície a oeste e influencia o escoamento lento das águas no ciclo anual das cheias e vazantes prolongando o período de elevação das águas (RESENDE apud FONSECA et al., 2017). Em direção à serra, terrenos acima da cota das inundações anuais, representam, historicamente, abrigo à população ribeirinha. A mesma função de abrigo nas cheias ou mesmo de local de moradia representam os aterros, naturais ou artificiais sendo estes originários do período de ocupação indígena da região. Referência ao papel de aterros como abrigo por residente de Barra de São Lourenço, informação extraída de Almeida e Silva (2012, p. 16): "Quando enche aqui nós vamos lá pro aterro do Piuval, aqui mesmo nessa região, porque é uma área mais alta, aí quando a água baixa nós volta para cá". Mesma prática de mobilidade espacial sazonal foi registrada por outros estudiosos, a exemplo de Siqueira (2015). Todavia, essas áreas, que são locais de segurança aos ribeirinhos nos períodos de inundação, encontram-se, hoje, dentro dos limites de unidades de conservação e com proibição de acesso.

Planície e serra formam um conjunto reconhecido nacional e internacionalmente como área de extremo interesse à preservação, o que fortalece políticas de preservação ambiental. Acrescentando sua beleza singular, o Pantanal está inscrito como Patrimônio Nacional pela Constituição Federal e Reserva da Biosfera e Patrimônio Natural da Humanidade pela UNESCO (MMA, 2010). A deslumbrante paisagem envolvendo o rio, baías e lagoas, a vegetação e a serra, além de recursos piscosos atrai o turismo nacional e internacional de pesca esportiva na região do Amolar, atividade que estimula serviços em Corumbá, distante 240 km, mas pouco beneficia a população ribeirinha.

A abertura da região para o turismo de pesca esportiva contrasta com as restrições impostas à pesca artesanal dos ribeirinhos. Este é um dos conflitos na região, pois, como afirmado pelos entrevistados, não se inibe a entrada de pescadores esportivos em áreas próximas do PARNA Pantanal e de RPPNs, fechadas apenas à população local. No entender local, as reservas particulares estendem seu poder sobre Áreas de Marinha, áreas públicas de controle da Superintendência do Patrimônio da União - SPU. Cercam, portanto, terras e águas que não Ihes são de direto. A esta prática fazemos analogia ao "cercamento dos campos" na história agrícola da Europa. Como no "cercamento dos campos", fragilizando e expulsando camponeses de grandes propriedades, o cercamento das unidades de conservação, inclusive de área de amortecimento, implica diretamente no cerceamento a recursos e ao modo de vida dos ribeirinhos. São expulsos de áreas outrora residenciais e dificultados em suas atividades de pesca e de agricultura e de acesso a outros recursos essenciais. A incerteza do ter onde morar e de como viver está no âmago do conflito socioambiental na região do Amolar.

\section{Os ribeirinhos, quem são eles?}

Duas questões são basilares na relação conflituosa dos ribeirinhos com as áreas protegidas. Uma é o não reconhecimento e marginalização da população residente pelos gestores ambientais que negam o caráter de identidade tradicional dos ribeirinhos, portanto, são desprovidos de direitos. Outra questão é se há real ameaça de suas práticas ao ecossistema local e regional, e qual seria o efeito de borda por ação antrópica da 
população que vive no entorno das áreas protegidas. Saber quem são e como vivem os ribeirinhos auxilia a elucidar essas questões.

Em primeiro lugar, os ribeirinhos constituem-se em um grupo social remanescente da "grande cheia" de 1974. São camponeses que exerciam ora atividades próprias e ora atividades de trabalho nas grandes fazendas de gado que havia na região. Suas atividades próprias envolviam a pesca, agricultura de alimentos básicos de pequena escala, caça e coleta. Mesclavam uma condição de camponês interno quando morador-trabalhador e de camponês independente quando em sua própria terra. Os que eram mais pescadores tinham uma característica móvel no rio, passando, em determinada época do ano, um período "rio acima" acampados com suas famílias - movimento semelhante à transumância em atividades agropastoris. Entrevistados relembram de seus pais ou de si mesmos nas relações com as antigas fazendas e com a pesca com deslocamentos sazonais das famílias.

No geral a população era espacialmente móvel segundo a disponibilidade de recursos naturais, o ciclo das águas de inundação e vazante e por oportunidades de trabalho. Conhecem a flora e fauna terrestre e aquática e a espacialidade e sazonalidade dos recursos naturais que Ihes são caros ao modo de viver. São brasileiros miscigenados com bolivianos e paraguaios e com ascendência indígena Guató. A ascendência indígena é perceptível pelo biotipo dos indivíduos, além de comprovada por especialistas a exemplo de Ribeiro e de Oliveira (apud SIQUEIRA, 2015) e, também, pelas práticas e apetrechos cotidianos na pesca, no uso de plantas medicinais nativas e outros (JESUS; LIMA, 2003). Esses hábitos podem ser não apenas influência por contato, mas transmitidos por casamentos interfamiliares. Um dos entrevistados é, notoriamente, indígena, inclusive com conhecimento do idioma guató e outro, espontaneamente, comentou "meu pai é mestiço, índio". Os Guatós consideram a todos seus parentes, estão sempre em contato com as comunidades e têm área própria na região, a Terra Indígena Guató com 12.716 hectares na ilha Ínsua criada em 1996. Estando na divisa com a Bolívia, há próximo a eles, na mesma ilha, o destacamento do Exército Brasileiro do Pantanal Porto Índio.

O passado e a história de vida não deixam dúvidas da ancestralidade dos ribeirinhos na região e da sua interação com a natureza, fonte de recursos e instigadora na construção de conhecimento e do saber prático do seu modo de vida em contínuo processo de adaptação às cíclicas e dinâmicas condições ambientais.

Com a "grande cheia" de 1974, pela sua intensidade, rapidez da inundação e lentidão de escoamento das águas, muito muda na região. Nas palavras de um entrevistado com referência aos fazendeiros: "dormiram ricos e acordaram pobres". Indicou, como exemplo, um fazendeiro que perdeu 20.000 cabeças de gado uma vez que suas terras se tornaram permanentemente alagadas. Pela extensão regional do evento, "não havia barco para tirar tanto animal de repente". Todavia, a cheia também teve forte impacto sobre a população em geral que sem trabalho e terras migrou em êxodo para Corumbá/Ladário. Mesmo em áreas menos susceptíveis a inundações como na comunidade do Amolar, o baque econômico desencadeado provocou forte evasão demográfica (AMÂNCIO et al., 2010).

A cheia de 1974 foi excepcional por ter sido associada a um evento extremo de erosão e sedimentação do rio Taquari que desemboca em delta no rio Paraguai. A foz 
do Taquari, o maior leque fluvial do mundo, teve uma deposição de sedimentos acima do normal, entulhando o leito do rio Paraguai (GALDINO et al., 2006). O fenômeno alterou o nível de base dos rios represando a montante nas sub-regiões Paraguai e Paiaguás grande volume de água, elevando a cota das inundações e alagando permanentemente áreas que ficavam anteriormente à margem das inundações ou afetadas sazonalmente.

A pecuária foi drasticamente reduzida com as fazendas falidas. Raros são aqueles que hoje se reconhecem como criadores ou fazendeiros em continuidade a um passado pecuarista promissor que ruiu repentinamente ocasionando brusca e forte queda no padrão de vida dos fazendeiros que não são "nem sombra do passado". Um dos depoimentos expõe bem essa situação:

Herdei 6.000 hectares dos pais, o que restou da enorme cessão de terras que meu bisavô ganhou no século XIX, que ficou cada vez mais dividida entre o grande número de herdeiros. Quando estava estudando em Pelotas para ser engenheiro meu pai morreu repentinamente, tive que abandonar os estudos e assumir a fazenda. Foi um infeliz acidente de vida porque logo depois a fazenda ficou alagada. Consegui manter 200 hectares de pasto usando saco de areia para conter a inundação. Os animais sumiram, só ficando só jacaré e peixe. Os vizinhos foram embora. Só sobrou meu gado e onça e jacaré foram em cima. De 120 cabeças de gado em 2014, perdi 16 para predadores e, de 80 carneiros, 30 foram perdidos. Os trabalhadores foram diminuindo e em 2013 foi dispensado o último. Hoje, toco a fazenda sozinho. A sede da fazenda ficou isolada. Só há acesso através de um pequeno rio entupido de vegetação que leva em barco de alumínio uma hora de viagem. Uma vez por semana ou quando posso trago a mulher para cá [comunidade de Paraguai Mirim] para ter contato com gente e ter com quem conversar (Pesquisa de campo, 2015).

A referência à diminuição de animais silvestres de médio porte também significa menor potencial de caça para a alimentação humana e maior perigo de animais predadores nas proximidades das áreas habitadas das comunidades, como relatos de ataques a cachorros e pequenas criações. Fazendas falidas e com baixo preço foram, com os anos, vendidas para empresários de fora da região. Em geral são inativas, havendo algumas com acomodações de lazer pessoal como para pesca ou visando futura instalação de atividades de turismo. As RPPNs são originadas de fazendas falidas e inativas e, como já apresentado, detêm milhares de hectares.

Além da aquisição de fazendas com mais de 10 mil hectares, é comum a aglutinação de várias a um único proprietário em nítido processo de concentração fundiária, verdadeiros latifúndios sob a máscara da proteção ambiental. A Ecotrópica detém, com quatro fazendas, 54.782 hectares. A fazenda Santa Tereza, iniciada em 2005 com a compra de uma propriedade de 23.000 hectares, em 2014, contava com 63.291 hectares após ter adquirido várias outras fazendas de diferentes dimensões. Essa fazenda, integrante da Rede de Proteção e Conservação da Serra do Amolar, é a única do grupo que desenvolve uma pecuária bovina. Estas fazendas/RPPN não representam a conti- 
nuidade de famílias de fazendeiros originais e não mantêm, propositalmente, nenhum vínculo com a população do seu entorno. Ao contrário, um traço comum a elas é a não contratação de trabalhadores de origem local. Os poucos contratados são todos vindos de fora.

Em direção à sub-região vizinha Paiaguás há fazendas ativas cujos proprietários são pantaneiros e embarcam animais para venda no porto da comunidade de São Francisco. Três dos entrevistados de Paraguai Mirim trabalham em fazendas do Paiaguás como campeiros e boiadeiros. Antes, um maior número de homens se empregava em fazendas da redondeza em tarefas temporárias. Trabalho, esse, hoje escasso. Sendo de famílias há gerações na região aprenderam os ofícios com os pais, em fazendas ou em atividades próprias. Atualmente, as atividades são quase unicamente dedicadas ao trabalho da família. Desenvolvem atividades produtivas para si na pesca, agricultura e extrativismo, poucos combinam estas com trabalho em fazendas, como seus pais o faziam (Tabela 1). São poucos os que buscam trabalho fora da região, no caso, geralmente filhos adultos em idade ativa de trabalho.

Tabela 1 - Origem da população ribeirinha e mobilidade de trabalho da família - 2015 (\%).

\begin{tabular}{l|c|c|c|c}
\hline Origem e mobilidade de trabalho & Região* & Corumbá & $\begin{array}{c}\text { Cuiabá/Campo } \\
\text { Grande }\end{array}$ & Outros \\
\hline Local de origem** & 98 & 1 & 1 & - \\
\hline $\begin{array}{l}\text { Local de trabalho de familiares de } \\
20 \text { a 59 anos }\end{array}$ & 84 & 8 & 2 & 6 \\
\hline Local residência e trabalho dos pais & 94 & 3 & 3 & - \\
\hline
\end{tabular}

* comunidades e fazendas próximas nos estados de Mato Grosso do Sul e Mato Grosso.

** nascidos e criados na região (maioria); nascidos em Corumbá e criados na região (minoria).

Fonte: Pesquisa de campo, 2015.

Após a cheia de 1974, fator de emigração de parte da população, os ribeirinhos que permaneceram na região tiveram que se adaptar a novas condições de vida, falta de trabalho, poucas e restritas áreas para agricultura, precarização de recursos e de produtos para fins mercantis. Tornaram-se mais pescadores e dependentes dos recursos naturais e passaram por um processo de involução econômica e aprofundaram o seu grau de subsistência, de uma situação de semi-subsistência para quase subsistência ${ }^{7}$. Retornam a uma atividade mais mercantil como coletores de iscas vivas para o turismo de pesca esportiva crescente na região e no estado pelas últimas décadas. Adaptam-se, assim, com o conhecimento dos recursos locais e práticas próprias a novas condições que o tempo Ihes impõe, possível pela tradição na região. 
Ribeirinhos, risco às unidades de conservação e ao ecossistema?

A questão fundiária - onde morar?

Uma vez que as evidências de ancestralidade e de histórico de vida local fundamentam o reconhecimento dos ribeirinhos na categoria de população tradicional conforme quesitos jurídicos pertinentes da legislação brasileira, resta saber se seu modo de vida representa uma ameaça como "efeito antrópico de borda" a comprometer a conservação do ecossistema protegido, alegação comum de ambientalistas no confronto com populações residentes no entorno de unidades de conservação ambiental. Argumento, este, na pauta do conflito dos gestores da Rede de Proteção e Conservação da Serra do Amolar, que reúne como parceiros unidades de conservação pública e particulares. Só faz sentido a restrição ao modo de vida local imposta aos ribeirinhos pelas unidades de conservação se suas práticas representarem comprovadamente uma interferência negativa no ecossistema.

É difícil sustentar que 64 famílias representam uma ameaça aos 276.087 hectares de área protegida das unidades de conservação ambiental já mencionadas. A esses milhares de hectares somam-se outros milhares que se estendem em região pantaneira no estado do Mato Grosso, como o Parque Estadual do Guirá com 100.000 hectares, o Parque Estadual Encontro das Águas com 108.000 hectares e ao Estação Ecológica de Taimã próximos ao PARNA Pantanal. Há ainda outros 12.716 hectares da Terra indígena Guató.

Estudos recentes do ICMBio visam a criação de outras unidades de conservação em Mato Grosso formando um mosaico interconectado de áreas públicas protegidas de enormes proporções, 887.855 hectares (BENTO FILHO, 2018). No conjunto, contíguo às reservas brasileiras, há no pantanal boliviano, Departamento de Santa Cruz, a Área Natural de Manejo Integrado San Matías criada em 1997 que se estende por uma superfície de 2.918.500 hectares (SERNAP, 2018).

Comparativamente a toda a área pantaneira em proteção ambiental, a extensão da comunidade de Barra de São Lourenço é de $12.241 \mathrm{~m}^{2}$ ou seja 1,22 hectares (SPU, 2016). Demais comunidades da região do Amolar devem ter extensões semelhantes, uma vez que o número de famílias é quase o mesmo e a disposição das habitações segue o mesmo padrão linear em estreita faixa de terra ao longo do rio.

Os ribeirinhos ocupam pequenas áreas e suas explorações são para uso próprio de subsistência. A área ocupada com residência é ínfima e poucos são aqueles que têm alguma cultura ou pequenas hortas. Espaço não é um problema concorrente às reservas. Mesmo assim, a praxe e o desejo das unidades de conservação é não tê-los à vista, nas reservas ou na vizinhança. Famílias foram expulsas das fazendas quando transformadas em reservas sem haver um plano e entendimento de realocação em outras áreas ou com compensações e indenizações. Famílias originárias de áreas internas do PARNA Pantanal e das fazendas/RPPNs Acurizal e Penha se fixaram na comunidade de Barra de São Lourenço e as oriundas da RPPN Eliezer Batista estabeleceram-se na vizinhança na comunidade de Paraguai Mirim. Após e em seguida à expulsão foram impostas restrições à pesca e outras atividades das famílias ribeirinhas, mesmo que tenham se estabelecido fora dos limites das reservas. 
Repetidos depoimentos desnudam ameaças e práticas de expulsão das fazendas transformadas em reservas. Falas dos ribeirinhos a pesquisadores revelam atos, não apenas ilegais, mas impensáveis em sua crueldade e insensibilidade humana realizados por gestores das unidades de conservação. Destacamos algumas:

[Fulanos $\mathrm{X}$ e Y] colocaram fogo na casa mandado pelo coronel $\mathrm{Z}$ do moinho. Coronel Z, ele quer colocar aqui a reserva dele que é a da MMX. Queimou no dia do enterro do meu marido. Trabalhava para eles na Fazenda Novo Dourados. Fui na reunião do Ministério Público Federal, eles vão ter que resolver e devolver o que foi queimado. Única família que ficou lá. Saíram quatro pessoas que ficavam na beira do rio. Mas ficamos. Tiraram foto dos meus filhos e disse que estávamos recebendo gente de fora. O coronel é da reserva MMX, vem fiscalizando e ameaçando. Proibiram a pesca (Paraguai Mirim, referência à expulsão de fazenda/Reserva Eliezer Batista, Pesquisa de campo, 2015).

Meu esposo pelotiava, ajudava o caseiro a rastilhá, carpi, tacá fogo no mato, pegá lenha e a mantê o zelo do rancho. Nóis morava lá e vivia daquilo. Tinha época que o serviço aumentava, nóis tinha que limpá a invernada, era muito bão. Mas, com o tempo, aquilo ali foi vendido pra um outro povo que pegô aquilo ali pra sê um parque de ecologia. [...] Aí logo que eles compraram, veio um tal de Divino, antigo piloteiro da fazenda, dando o aviso. Ele chegou e disse assim: "Olha eu vim aqui porque os donos mandaram avisá vocês que agora essa terra é uma reserva e que eles não qué que corta mais um gaio de pau, eles não qué mais que roce, que queime, que mais nada e que vocês desocupem o lugar". [...] Na hora eu pensei: pra onde nóis vai se esse é nosso trabalho? Naquele ano, o turismo ainda não era forte na região, e nóis não tinha nem onde morá. Nem paia e pau nóis pudemo cortá pra montá nossas casas. Nossa sorte foi que o cumpadi Vando morava aqui nessa ilha e convidô nóis pra vim pra cá. Embarcamo na nossa canoa e viemo, depois o resto do povo começou a vim e limpá cada um o seu pedaço de terra. [...] Dava até um desespero, nóis não tinha mais nenhuma parede, nóis não tinha mais nada. Mas, nós lidemo até consegui nosso lugar (Barra de São Lourenço, referência à expulsão da fazenda/ RPPN Acurizal, ZANATA, 2011, p. 38).

Como nasci e me criei na Serra do Amolar, conheço todas as famílias da comunidade, e foi assim que a ONG me contratou para avisar a todos que deveriam sair dali em uma semana, porque tudo tinha virado reserva [...] As famílias me pediram que pedisse ao novo dono da fazenda que ajudasse pelo menos com lonas e barco para o transporte, já que só possuíam canoas e estavam com crianças, mas tudo foi negado (referência à expulsão da fazenda/RPPN Acurizal/ Penha, SIQUEIRA, 2015, p. 52).

Com a criação da reserva particular, tive que deixar minha casa de um dia pro outro. Deixamos nossas coisas "pra" trás, apenas pegamos a mala e colocamos 
no barco. Grávida e com muito medo, acabei perdendo a criança. Era "pra" se chamar Ana Rosa (Barra de São Lourenço, com referência à expulsão da fazenda/RPPN Acurizal/Penha, SIQUEIRA, 2015, p. 57).

Expulsão é mais reportada na fazenda da RPPN Acurizal/Penha. Por ter áreas mais elevadas e morros em direção à serra do Amolar, protegidas das inundações, era onde residia a maioria das famílias da comunidade de Barra de São Lourenço. Ao contrário dos fatos, o plano de manejo das RPPNs Acurizal, Penha e Dorochê apresenta a área da fazenda como "livres de ocupação de terceiros" (ECOTRÓPICA, 2003, p. xviii). Entretanto, as terras livres de ocupação assim o eram após processos de expulsão de famílias. A prática de expulsão, contudo, foi recorrente às demais unidades de conservação e a todas as fazendas com novos proprietários, mesmo que não transformadas em RPPN. Na comunidade de Paraguai Mirim, encontram-se famílias ex-moradoras internas de fazendas e ex-residentes da margem direita do rio Paraguai. A expulsão da margem do rio com atos de violência, reportada em entrevistas é também registrada pela ECOA (2016a). Gestores das RPPNs se firmam na alegação de que os limites das fazendas estendem-se até o rio Paraguai. Hoje, ribeirinhos entendem que as margens são terras da União. A sobreposição de terras públicas e privadas é observada em Siqueira (2015).

Mesmo que em condições fundiárias vulneráveis por não terem títulos de propriedade, os ribeirinhos poderiam estar protegidos por direitos de usucapião ou como posseiros pelo tempo e gerações de ocupação. Não tinham conhecimento e nem foram orientados a requisitar direitos fundiários como esses. O reconhecimento como população tradicional também é recente.

\section{Modo e Qualidade de vida - risco ambiental?}

Sem trabalho nas fazendas, sem terra para plantar e criar, os ribeirinhos tornam-se essencialmente pescadores. Sempre o foram em meio à diversidade de outras atividades que praticavam, mas a pesca sobrepõe-se, hoje, a outras atividades. Com fins mercantis, praticam a captura de iscas vivas para o turismo de pesca esportiva. Da moradia à alimentação e a bens fundamentais, são dependentes dos recursos da natureza. Porém, isso não significa que seu modo de vida seja lesivo e cause dano ao ecossistema. A escala de uso dos recursos é pequena e assumir a priori que a ação antrópica dos ribeirinhos ameaça o ecossistema sem um levantamento e estudo específico sobre eles é preconceituoso e prejulgamento.

Gestores ambientais e ambientalistas tendem a uma visão apriorista expressa nos planos de manejo das reservas e nas restrições que são impostas à população sem conhecer suas práticas e modo de vida. Não há estudos comprobatórios que sustente de forma consistente haver uma ação antrópica predatória dos ribeirinhos. Ao contrário, o diagnóstico da região hidrográfica do rio Paraguai realizado pela Agência Nacional de Águas - ANA (2017) - aponta comprometimentos ao ecossistema pantaneiro por causas externas e alheias ao Amolar: as cidades, principalmente pela falta de saneamento, obras de infraestrutura como barragens e estradas, mineração e o agronegócio no planalto, este 
como grande contribuidor de poluentes e de sedimentos transportados para a planície. A ocupação rural ribeirinha não demostrou problemas na qualidade da água e demais elementos da bacia.

Apesar disso, aos ribeirinhos da região do Amolar têm sido impostas severas restrições ao uso de recursos naturais com o argumento da proteção ambiental e sobre eles recaem os custos sociais da política ambiental. Alega-se para tal a proximidade do PARNA Pantanal, o contato/vizinhança com as RPPNs e a precaução macro-regional ao conjunto de toda a bacia do alto Paraguai. Porém, as pesquisas sociais e as ecológicas não seguem metodologias integradoras e não dialogam entre si para justificar restrições que comprometam o modo de vida local. Somente um estudo integrado investigando a interação do modo de vida local com os recursos naturais pode com confiabilidade responder sobre o efeito da ação antrópica dos ribeirinhos do Amolar sobre o ecossistema local e regional do Pantanal. Mas, considerando a literatura, faltam estudos precisos sobre as atividades extrativas dos ribeirinhos em relação aos recursos úteis, sua recomposição e a dinâmica geral do ecossistema - ponto chave para inferir sobre a interferência da ação antrópica dos ribeirinhos do Amolar. Destacamos que são apenas 64 famílias em regime de subsistência ocupando pequena área.

Os ribeirinhos, se em passado recente, além da pesca produziam alimentos para consumo e parte para comercialização em Corumbá, atualmente pouco produzem de agricultura e de criação de animais. Quando produzem, é exclusivamente para subsistência e vendas esporádicas a vizinhos. Monetariamente praticam a pesca em pequena escala e a captura de iscas vivas para o setor turístico (Figuras 1 e 2).

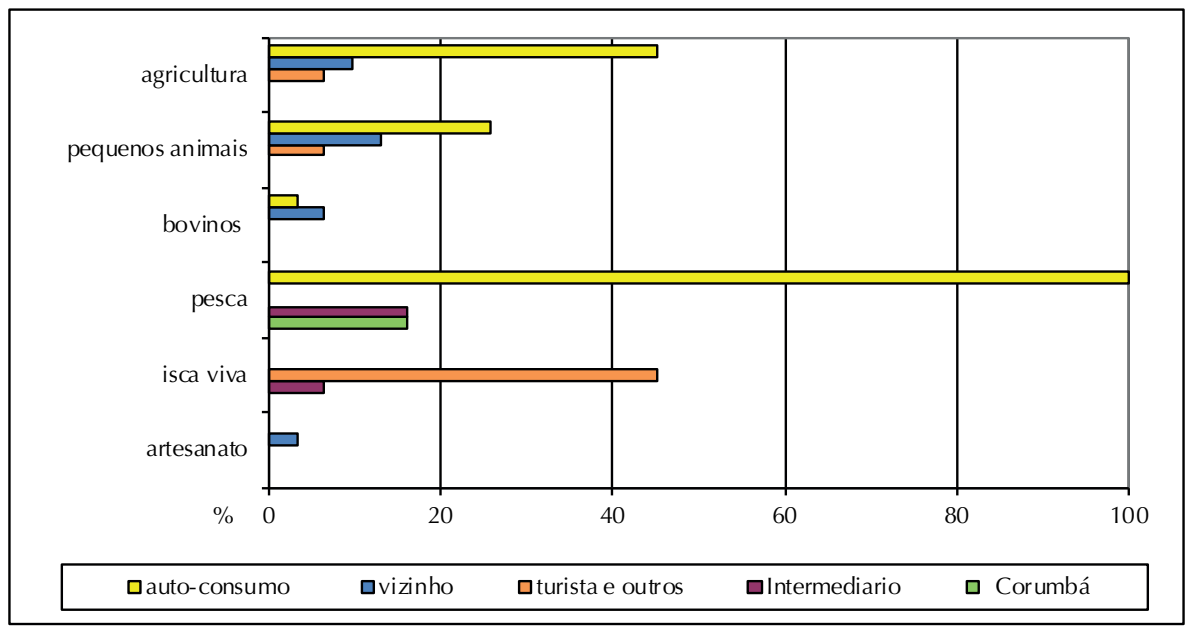

Figura 1: Atividades executadas na família.

Fonte: Pesquisa de campo, 2015. 




Figura 2: Consumo e venda de produtos.

Fonte: Pesquisa de campo, 2015.

Explicitando como são as atividades, cerca de 50\% dos entrevistados informaram que têm alguns plantios em áreas próximas às suas residências, mas são plantios diminutos (menos de 1 ha), pois não há área disponível. Mesmo assim, tentam produzir alimentos básicos, mesmo que em pouca quantidade e insuficiente às necessidades alimentares da família. Entre os cultivos sobressaem a mandioca, o milho, a banana, a batata e a presença de fruteiras. A criação se resume a uns poucos animais criados à solta, 2 a 4 porcos (no máximo, e, caso raro, 10 animais), galinhas em torno de 20 poedeiras que após um tempo são abatidas. Aqueles que não têm nenhuma disponibilidade de terreno são os que criam pequenos animas e à solta. Três famílias criam gado bovino, em torno de 20 a 30 reses, para consumo e venda a vizinhos de leite, queijo e eventualmente carne. Estes são casos raros e a atividade é incompatível com as comunidades, pois sem área de pastagem os animais ficam soltos, invadem espaço de vizinhos e causam atritos. Enfaticamente, todos afirmaram que não se utilizam do fogo para o plantio. Esta é uma alegação de RPPNs ao se colocarem contrários à presença dos ribeirinhos. Comum prática de agricultura de roça no Brasil, o uso do fogo na agricultura parece estar eliminado entre os ribeirinhos locais.

A produção permanece nas comunidades para autoconsumo das famílias e uma menor parte é vendida localmente em pequenas quantidades a vizinhos ou a integrantes de instituições que prestam ocasionalmente serviço de atendimento social na região. Problemas apontados para a agricultura e criação foram a falta de espaço e terrenos com nível elevado do lençol freático que prejudica o crescimento das plantas e apodrece as raízes.

A produção de alimentos é insuficiente, principalmente no período das chuvas e de defeso da pesca. A escassez de alimentos é em parte compensada pelo Programa Social 
Povo das Águas da prefeitura de Corumbá, iniciado em 2009, que distribui cestas básicas no período das chuvas e presta ações assistenciais de forma geral.

É do rio a maior garantia de alimentos e também de onde conseguem alguma renda monetária comercializando peixe e iscas vivas. Todos pescam para alimentação da família. Cerca de um quarto dos entrevistados pesca visando comercializar; sendo que metade desses vende o pescado a um intermediário local e a outra metade, tendo embarcações de capacidade de viagem de longa distância, vende diretamente a varejistas de Corumbá. A pesca é artesanal, locomovem-se em canoas a remo e com vara de empuxo, algumas com motor adaptados à navegação fluvial, as chamadas de "rabetas". A renda média advinda do pescado é de $\mathrm{R} \$ 5.388,00$ ao ano por família pescadora, por mês equivaleria a 63,3\% do salário mínimo mensal de R\$788,00 da época (Tabela 2). Entretanto, é a captura de iscas vivas que garante à maioria um produto comercial. Iscas vivas - tuvira (gymnotidae) e caranguejo (trichodactylidae) - são 100\% comercializadas localmente, sendo a grande maioria vendida diretamente a embarcações de turismo de pesca esportiva, onde se obtém um melhor preço. Todavia, apesar de ser uma atividade mais comum envolvendo $65,4 \%$ das famílias, o retorno econômico é menor, R\$ 3.484,00 ao ano, ou seja 36,8 \% do salário mínimo.

Tabela 2 - Renda média familiar estimada por atividade - 2014 (R\$).

\begin{tabular}{l|c|c|c|c}
\hline \multirow{2}{*}{$\begin{array}{l}\text { Renda familiar estimada } \\
\text { por atividade* }\end{array}$} & \multicolumn{2}{|c|}{$\begin{array}{c}\text { Renda média } \\
\text { (R\$) }\end{array}$} & $\begin{array}{c}\text { Salário mínimo } \\
\%\end{array}$ & $\begin{array}{c}\text { Famílias } \\
\%\end{array}$ \\
\cline { 2 - 3 } & ano & Mês & 17,3 & 11,5 \\
\hline Agricultura/criações & 1.633 & 136 & 56,8 & 7,7 \\
\hline Bovinos & 5.300 & 442 & 63,3 & 26,9 \\
\hline Pescado & 5.388 & 499 & 36,8 & 65,4 \\
\hline Isca-viva & 3.484 & 290 & 4,2 & 3,8 \\
\hline Artesanato & 400 & 33 & 57,0 & 7,7 \\
\hline Empregado em fazenda & 5.390 & 449 & 86,5 & 7,7 \\
\hline Atividade não agrícola & 8.180 & 682 & & 72 \\
\hline
\end{tabular}

* estimativa por exemplos de valores informados e $\mathrm{n}^{\circ}$ de famílias nas atividades avaliadas.

Fonte: Pesquisa de campo, 2015.

Tanto no pescado, quanto nas iscas vivas, a captura é sazonal, significando que além da pouca renda gerada, as famílias enfrentam períodos sem ganho por vários meses, meses coincidentes com o mesmo período de escassez de produção agrícola. Vivem abaixo da linha de pobreza por parâmetros oficiais. Famílias com filhos em idade escolar 
recebem o auxílio bolsa família, mas dos benefícios sociais é a aposentadoria que faz a diferença. Um terço das famílias contatadas tem pelo menos um membro familiar recebendo aposentadoria no valor de um salário mínimo. Também conseguem uma renda maior quando famílias nucleares unidas por gerações de descendentes - pais, filhos e netos - em trabalho conjunto e compartilhando equipamentos conseguem uma escala superior de produção do que se trabalhassem sozinhas. Situação nítida na pesca e captura de iscas vivas e que possibilita ainda praticar atividades agrícolas.

A tuvira é a isca mais valorizada, atingiu em 2014 R\$ 0,80 a unidade vendida a turistas de pesca. Mas há aqueles que vendem para um intermediário que reside na região e, no caso, a diferença de preço é expressiva, recebendo R\$ 0,40 a R\$ 0,50 por tuvira, uma diferença de preço de cerca de $100 \%$ entre os dois tipos de transação. Caranguejo, no mesmo ano, foi comercializado entre $\mathrm{R} \$ 0,60$ e $\mathrm{R} \$ 0,70$ a unidade. A diferença do valor comercializado aproxima-se da registrada em estudo de Catella et al. (2008) entre venda ao turista e venda a atravessador.

A demanda por iscas vivas está associada ao turismo de pesca esportiva crescente e o Pantanal desponta nesse circuito nacional e internacionalmente há décadas. Esta pesca atinge cerca de $50 \%$ do volume de todo o pescado do estado (CATELLA et al., 2017). Esse turismo está na base da captura de iscas vivas, e tanto o pescado quanto as iscas vivas são preocupações de ictiólogos em defesa de controles regulatórios de ambos. Uma vez que iscas vivas representam o principal recurso de valor monetário para a maioria dos ribeirinhos, o seu controle e regularização junto à pesca e o turismo deve compatibilizar, ao mesmo tempo, o recurso em si pelo seu fim utilitário e o processo de sua recomposição/ reprodução e as necessidades das populações.

A observar que as atividades não respondem por condições satisfatórias de qualidade de vida dos ribeirinhos. O ganho monetário é baixo, não são autossuficientes na produção de alimentos, suas moradias são precárias e constantemente ameaçadas pelo nível das inundações uma vez que residem hoje em áreas mais vulneráveis às cheias e susceptíveis a processos de erosão fluvial natural e do tráfego de embarcações do turismo de pesca (FONSECA et al., 2017).

Subjacente à qualidade de vida dessa população ribeirinha, em um primeiro momento, está o reconhecimento de seus direitos fundiários ou dominiais e de seu modo de vida interagindo com o rio e com recursos naturais diversos, o que lhes conferirá segurança em seu local de vida. Todavia, para melhoria de suas precárias condições de vida, é preciso ir além, de forma a ampliar habilidades e conhecimentos para seu sustento e ao menos tempo para a convivência com a conservação ambiental.

\section{Parcerias, Visibilidade e Mediação de Conflitos}

Em sua resistência frente às restrições e ameaças por parte das unidades de conservação, os ribeirinhos têm tido o suporte de algumas instituições governamentais e organizações não governamentais atuantes na região. Sobressaem, entre elas, o Ministério Público Federal e a organização não governamental Ecologia em Ação - ECOA. São também atuantes localmente pesquisadores da Universidade Federal de Mato Grosso do Sul, campus de Corumbá, e da EMBRAPA. 
Um dos pontos principais para enfrentar as arbitrariedades das unidades de conservação foi a união dos ribeirinhos com a formação de associações comunitárias. Apesar de ajuda mútua entre parentes e vizinhos em sua história, a população não era organizada em torno de questões coletivas. Associações foram criadas em cada local de agrupamento de famílias com assessoria e contato pessoal constante da ECOA, e são também estimuladas pelo Ministério Público Federal. As associações formam a base da unidade e identidade comunitária, propiciam visibilidade às questões locais e permitem encaminhar reivindicações coletivas a órgãos competentes.

A ECOA, atuante na região desde 2005, é decisiva na articulação das instituições presentes e com trabalhos junto aos ribeirinhos. Também assiste à população com orientações de extensão e cessão de equipamentos e busca vias para melhorias na qualidade de vida e da produção de forma participativa. Como protagonista e de confiança dos ribeirinhos, dá suporte e estimula estudos diagnósticos e de inovação local e conecta-se a pesquisadores de diferentes órgãos, como a EMBRAPA e universidades, pesquisadores, professores e alunos. A atuação participativa atraindo indivíduos e instituições resultou na formação de uma rede social extensa. Na rede os ribeirinhos têm conseguido assistência social especializada, como o já mencionado Programa Povo das Águas, a construção de escolas nas comunidades, a obtenção de documentos e até aposentarias, benefício que, por não saberem que tinham direito e que preenchiam os quesitos, não era solicitado.

Nas questões cruciais de resolução do direto à terra e do direito à pesca, o Ministério Público Federal - MPF - é o agente na mediação jurídica. Resulta da mediação a concessão à comunidade de Barra de São Lourenço pela Superintendência de Patrimônio da União - SPU - o Termo de Autorização de Uso Sustentável Coletivo ${ }^{8}$ - TAUS - em 2013 para uso sazonal para moradia e uso extrativista do Aterro do Socorro, também conhecido como Piuval com 13,9 hectares. É uma permissão de retorno e de exploração de recursos naturais em locais de uso tradicional por gerações (ECOA, 2016a; MPF, 2013).

O Aterro do Socorro, área de 13,9 hectares e com altimetria de 101 metros, na margem direta do rio Paraguai e local de moradias no passado da população, está 8 metros mais elevado do que o atual local de Barra de São Lourenço, na cota de 93 metros e, assim, se torna um abrigo durante períodos de cheias excepcionais (ECOA, 2016a; SIQUEIRA, 2015). A pouca diferença de altitude é suficiente para a população se proteger das inundações como a ocorrida em 2014. A concessão do aterro à população ribeirinha de decisão do MPF e SPU foi por mais de uma vez contestada pelas RPPNs Acurizal e Penha com a alegação de sua importância para a conservação, estando dentro da área dessas reservas. Mandados de segurança e processo contra do SPU contestando o TAUS têm sido indeferidos pela justiça federal (SIQUEIRA, 2015).

As áreas residenciais de Barra de São Lourenço a Paraguai Mirim passam a ser consideradas de destinação à regularização fundiária do SPU e conferido o RIP - Registro de Imóvel Patrimonial - aos moradores em 2011 e 2012 (SPU, s.d.). Em Barra de São Lourenço, local mais vulnerável às pressões das reservas e reforçando a concessão da moradia, foi também outorgado aos moradores da comunidade pelo SPU em Portaria 57 de 7 de abril de 2016 o Termo de Autorização de Uso Sustentável - TAUS - de terrenos marginais de rio federal correspondentes a toda a área da comunidade, denominada Aterro da Binega, com 12.241 m², ou seja 1,2 hectares (SPU, 2016; ECOA, 2016b). Com essas outorgas os 
ribeirinhos tornam-se beneficiários de regulação fundiária de imóveis em terras da União (Brasil, 2017; SPU, s.d.). Uma outra e recente conquista dessa comunidade em resposta à reivindicação de acesso a áreas de pesca, é alcançada em 2019 com a revisão do plano de manejo do PARNA Pantanal imposta por decisão judicial em 2015 e liminar em 2017 do Ministério Público Federal. A decisão do MPF foi tomada "com base em uma série de estudos, inclusive parecer técnico da Embrapa, que garantem que as atividades pesqueiras e extrativistas da comunidade não comprometem os recursos naturais do local" (MPF, 2019, p. 1) e considera o ICMBio omisso às condições dos ribeirinhos. O plano de manejo foi revisto e ampliada a área de pesca dos comunitários em trechos dos rios Paraguai e São Lourenço/Cuiabá mediante a Portaria 633 de 23 de outubro de 2019 do ICMBio (ECOA, 2018; MMA/ICMBio, 2019). Outra medida, mas ainda em tramitação, é uma solicitação de 2012 do Ministério Público Federal acompanhado de abaixo assinado dos ribeirinhos para criação de uma Reserva Extrativista ou de Desenvolvimento Sustentável (MPF, 2013) sob a gestão dos ribeirinhos. Se concretizada significaria o reconhecimento de seu território de vida e de novas opções no uso do espaço em interação com a natureza.

\section{Conclusão}

A visão e prática dos gestores das unidades de conservação ambiental das RPPNs na região do Amolar são intransigentes e os direitos da população tradicional são tolerados apenas por imposição de decisões jurídicas que os obrigam a aceitar a presença dos ribeirinhos. A alegada contribuição para a sociedade e o bem-estar da população local pregado pelas RPPNs estão desvinculados da prática. Em verdade, elas seguem uma prática de discurso de natureza pristina e bela sem a presença humana e sem compromisso social. Representam um grupo de empresários com força politica investindo em terras sob o aparato da conservação. Conseguem, inclusive, cooptar gestores e instituições públicos como o ICMBio. Isso em si é uma contradição à própria origem da instituição que expressa em seu próprio nome - Chico Mendes - o líder seringalista no conflito com fazendeiros grileiros que se tornou símbolo de movimentos de resistência e permanência de populações vulneráveis ameaçadas.

O que ocorre na região do Amolar é um processo advindo da economia verde que visa acumulação por conservação, através de vantagens de pagamento por serviços ambientais e benefícios e incentivos fiscais, além da extrema concentração de terras. É um processo global que envolve organizações não governamentais transnacionais que formam redes de acumulação através da conservação em diferentes escalas, que tornam o uso não material da natureza em grande fonte de capital (BÜSCHER; FLETCHER, 2014).

Os ribeirinhos conseguiram resistir e subsistir às pressões, ameaças e atos ilegais das RPPNs, inicialmente de maneira precária, mas foram fortalecidos quando se integraram na formação de uma rede de atores com visão socioecológica na conservação da natureza. Colocam-se em contraposição à rede biocêntrica das RPPNs. A troca de conhecimentos e práticas entre os aliados e parceiros corroborou com o processo de resistência e deu garantia jurídica de permanência no lugar. A garantia do direito à terra é basilar para uma nova etapa na busca de alternativas para a melhoria da qualidade de vida. 
O ICMBio poderia ter sido um grande aliado. Infelizmente sua opção foi aderir às RPPNs abandonando a população local, mesmo sabendo de sua vulnerabilidade. Ao mesmo tempo, o potencial dos conhecimentos empíricos, advindos do modo de vida dos ribeirinhos sobre a natureza local não puderam ser compartilhados. Quando muito, fez-se um rol de alguns recursos naturais utilizados, como o de plantas medicinais (JESUS; LIMA, 2003). Uma aproximação com os ribeirinhos entendendo seu modo de vida, valorizando seu conhecimento, poderia contribuir para um protagonismo de conservação com responsabilidade social. Em momento de revisão do plano de manejo do PARNA Pantanal, o compartilhamento de saberes poderia ir para além do foco de identificação e delimitação de áreas de pesca.

Pelas forças do poder político e econômico na região, é difícil prever a criação de uma reserva de desenvolvimento sustentável como foi proposto pelo Ministério Público Federal. Se fosse concretizada, seria o coroamento da permanência e de uso sustentável dos recursos naturais e uma solução às pressões das RPPNs. Uma reserva sob a gestão dos ribeirinhos lhes proporcionaria reais oportunidades para melhoria da qualidade de vida com novas explorações e atividades. Também Ihes abriria oportunidades para recebimento de recursos financeiros públicos e de outras fontes para a conservação ambiental como ocorre com unidades de conservação oficialmente reconhecidas. Turismo comunitário com potencial ecológico e cultural e a exploração de produtos nativos já conhecidos, como frutos, plantas medicinais, arroz "campeiro/ selvagem" (oryza glumaepatula e oryza latifólia), fibras nativas e outros poderiam ser estimulados a partir de práticas domésticas. Mesmo que a reserva não seja criada, ribeirinhos com sua rede de parceiros devem agora seguir na direção da resiliência sendo ativos em novos contatos, novas propostas e inovações.

\section{Referências Bibliográficas}

AB'SABER, A. N. O Pantanal Mato-grossense e a teoria dos refúgios. Revista Brasileira de Geografia, v. 1, n. 1, p. 9-57, 1939.

ACSELRAD, H. Justiça ambiental e construção social do risco. Desenvolvimento e Meio Ambiente, n. 5, p. 49-60, 2002.

Ambientalização das lutas sociais - o caso do movimento por justiça ambiental. Estudos Avançados, v. 24, n. 68, p. 103-115, 2010.

ADAMS, W.; MULLIGAN, M. Introduction. In: ADAMS, W.; MULLIGAN, M. (Orgs.). Decolonizing nature: strategies for conservation in a post-colonial era, p. 1-15. Londres: Earthscan, 2003.

AGÊNCIA NACIONAL DE ÁGUAS (ANA). Plano de recursos Hídricos da Região Hidrográfica do Paraguai - PRH Paraguai, Produto Parcial PP 02 - Diagnóstico Consolidado da Região Hidrográfica do rio Paraguai. Brasília: ANA/SPR, ENGECORPS Engenharia S.A., 2017.

Espaço Aberto, PPGG - UFRJ, Rio de Janeiro, V. 10, N.2, p. 205-235, 2020

ISSN 2237-3071

DOI: 10.36403/espacoaberto.2020.38022 
ALMEIDA, M. A.; SILVA, C. J. Educação ambiental: práxis de uma comunidade tradicional no entorno do Parque nacional do Pantanal Mato-grossense. Educação, Cultura e Sociedade, v. 2, n. 2, p. 78-93, 2012.

AMÂNCIO, C. O. G.; AMÂNCIO, R.; TONIAZZO, R. C.; BOTELHO, D.; PELLEGRIN, L. A. Caracterização socioeconômica da comunidade do Amolar, sub-região do Paraguai, Corumbá, MS. Circular Técnica 92. Corumbá: Embrapa Pantanal, 2010.

BENTO FILHO, W. Estudos reforçam aptidão para mosaico de UCs no Pantanal. 2018. Disponível em: https://uc.socioambiental.org/pt-br/noticia/193950. Acesso em: 26 jun. 2020.

BICALHO, A. M. S. M. Capital social na várzea amazônica. In: BICALHO, A. M. S. M.; GOMES, P. C. C. (Orgs.). Questões metodológicas e novas temáticas na pesquisa geográfica, p. 116-145. Rio de Janeiro: PUBLIT, 2009.

BLAIKIE, P.; BROOKFIELD, H. Land degradation and society. Londres: Metheun, 1986.

BRASIL. Decreto n 68.691, de 28 de maio de 1971. Cria a Reserva Biológica do Caracará, no Estado de Mato Grosso, com os limites que especifica e dá outras providências. Diário Oficial da União - Seção 1 - 31/5/1971, p. 4091.

Decreto $n^{\circ}$ 86.392, de 24 de setembro de 1981. Cria, no estado de Mato Grosso, o Parque Nacional do Pantanal Mato-grossense. Diário Oficial da União, Seção 1, 25/9/1981, p. 18022.

. Decreto $n^{\circ} 5.746$ de 5 de abril de 2006. Regulamenta o art. 21 da Lei no 9.985, de 18 de julho de 2000, que dispõe sobre o Sistema Nacional de Unidades de Conservação da Natureza. Diário Oficial da União, Seção 1, 6/4/2006, p. 1.

Decreto $n^{\circ}$ 6.040. de 7 de fevereiro de 2007. Institui a Política Nacional de Desenvolvimento sustentável dos povos e Comunidades Tradicionais. Diário Oficial da União, Seção 1, 8/2/2007, p. 316.

Lei $n^{\circ} 13.465$, de 11 de julho de 2017. Dispõe sobre a regularização fundiária rural e urbana, sobre a liquidação de créditos concedidos aos assentados da reforma agrária e sobre a regularização fundiária no âmbito da Amazônia Legal; institui mecanismos para aprimorar a eficiência dos procedimentos de alienação de imóveis da União, e dá outras providências. Diário Oficial da União, Seção 1, 8/9/2017, p. 1.

BUMPUS, A. G.; LIVERMAN, D. M. Carbon colonialism? In: PEET, R.; ROBBINS, P.; MATTS, J. (Orgs.). Global political ecology, p. 203-224. Milton Park: Routledge, 2011.

BÜSCHER, B.; FLETCHER, R. Accumulation by conservation. New Political Economy, v. 20, n. 2, p. 273-298, 2014. 
. Under pressure: conceptualising political ecologies of green wars. Conservation and Society, v. 16, n. 2, p. 105-113, 2018.

CATElla, A. C; SILVA, S. M. V.; FERNANDES, J.; AMÂNCIO, C. O. G.; MORAES, A. S. Estimativa da renda bruta dos pescadores de iscas vivas do Porto da Manga, Corumbá (MS). Circular Técnica 79. Corumbá: Embrapa Pantanal, 2008.

CATELlA, A. C.; CAMPOS, F. L. R.; ALBUQUERQUE, S. P. Sistema de Controle da Pesca de Mato Grosso do Sul SCPESCA/MS 23 - 2016. Boletim de Pesquisa e Desenvolvimento 133. Corumbá: Embrapa Pantanal, 2017.

CONSELHO NACIONAL DOS DIREITOS HUMANOS (CNDH). Povos livres, territórios em luta: relatório sobre os direitos dos povos e comunidades tradicionais. Brasília: CNDG, 2018.

CRONIN, W. Changes in the land. Indians, colonists, and the ecology of New England. Nova York: Hill \& Wang, 1983.

. Nature's metropolis. Nova York: Norton, 1991.

CROSBY, A.W. Ecological imperialism. Cambridge: Cambridge University Press, 1986.

DOWIE, M. Conservation refugees: the hundred-year conflict between global conservation and native peoples. Cambridge: MIT Press, 2009.

ECOA (Ecologia e Ação). Comunidades tradicionais: Paraguai Mirim e São Francisco, 2014a. Disponível em: http://riosvivos.org.br/comunidades/comunidades-tradicionais-comunidades/ paraguai-mirim-e-sao-francisco. Acesso em: 25 fev. 2016.

Comunidades tradicionais: Barra de São Lourenço, 2014b. Disponível em: http:// riosvivos.org.br/comunidades/comunidades-tradicionais-comunidades/barra-do-sao-lourenco. Acesso em: 25 fev. 2016.

Comunidades tradicionais: Serra do Amolar, 2015. Disponível em: http://riosvivos.org.br/comunidades/comunidades-tradicionais-comunidades/serra-do-amolar. Acesso em: 25 fev. 2016.

TAUS no Pantanal - um instrumento protetor de comunidades vulneráveis, 2016a. Disponível em: https//ecoa.org.br/taus-no-pantanal-um-instrumento-protetor-de-comunidades vulneráveis. Acesso em: 07 maio 2020.

SPU declara ser de interesse público área da comunidade de São Lourenço, 2016b. Disponível em: https://ecoa.org.br/spu-declara-ser-de-interesse-publico-area-da-comunidade-de-sao-lourenco. Acesso em: 07 maio 2020. 
. Parque Nacional do Pantanal Matogrossense e comunidade tradicional começam revisão do Plano de Manejo, 2018. Disponível em: https//ecoa.org.br/parque-nacional-do-pantanal-matogrossense-e-comunidade-tradicional-começam-revisão-do-plano-de-manejo. Acesso em: 07 maio 2020.

ECOTRÓPRICA (Fundação de Apoio à Vida nos Trópicos). Plano de manejo das RPPNs Acurizal, Penha e Dorochê. Cuiabá, 2003

FAO (Food and Agriculture Organization). Evidence-based Assessment of the Sustainability and Replicability of Integrated Food-energy Systems. Environmental and natural resources management working paper, Energy, 57. Roma, 2014.

FONSECA, T. P. L.; SILVA, A.; SILVA, B. L. P. A influência da cheia na comunidade da Barra do São Lourenço Pantanal Sul-Matogrossense. GeoPantanal, número especial, p. 447-459, 2017.

GALDINO, S.; VIEIRA, L.M.; PELLEGRIN, L.A. (Orgs.). Impactos Ambientais e Socioeconômicos na Bacia do Rio Taquari - Pantanal. Corumbá: EMBRAPA Pantanal, 2006.

GRIFFON, C.; JONES, R.; ROBERTSON, I. (Orgs.). Moral ecologies: histories of conservation, dispossession and resistance. Cham: Palgrave Macmillan Spinger, 2019.

HARVEY, D. Seventeen contradictions and the end of capitalism. Londres: Profile, 2014.

HOEFLE, S. Ghosts in the forest: the moral ecology of environmental governance toward poor farmers of the Brazilian and US Atlantic Forests. In: GRIFFON, C.; JONES, R.; ROBERTSON, I. (Orgs.). Moral ecologies: histories of conservation, dispossession and resistance, p. 99-125. Cham: Palgrave Macmillan Spinger, 2019.

HOLIFIELD, R. Environmental justice and political ecology. In: PERREAULT, T.; BRIDGE, G.; McCARTHY, J. (Orgs.). Routledge handbook of political ecology. Milton Park: Routledge, p. 585-597, 2015.

INSTITUTO ACAIA. Serra do Amolar. 2014. Disponível em: acaia.org.br/wp-content/ uploads/2007/07/RPCSA_2014_Apres_v2.pdf. Acesso em: 4 nov. 2019.

JACOBY, K. Crimes against nature: squatters, poachers, thieves. Berkeley: University of California Press, 2014.

JESUS, F.; LIMA, S. F. Plano de Manejo do Parque Nacional do Pantanal Matogrossense. Brasilia: ICMBio, 2003.

KELLY-REIF, K.; WING, S. Urban-rural exploitation: an underappreciated dimension of environmental injustice. Journal of Rural Studies, v. 47, p. 350-358, 2016. 
MACEDO, H. A., STEVAuX, J. C., SILVA, A., MERINO, E. R., LO, E. L., ASSINE, M. L. Hydrosedimentology of the paraguay river in the Corumbá fluvial reach, pantanal wetland. Revista Brasileira de Geomorfologia, v. 20,n. 2, p. 255-271, 2019.

MERCHANT, C. Radical ecology. Londres: Routledge, 1992.

MMA/IBAMA (Ministério do Meio Ambiente, dos Recursos Hídricos e da Amazônia Legal). Portaria $n^{\circ} 6$ (criação RPPN Fazenda Estância Dorochê) e Portaria $n^{\circ} 7$ (criação da RPPN Fazenda Acurizal e Fazenda Penha) de 19 de fevereiro de 1997. Diário Oficial da União, n. 34, Seção 1, p. 3242, 20/2/1997.

MMA/ICMBio (Instituto Chico Mendes de Conservação da Biodiversidade). Portaria n 51 de 24 de julho de 2008 (criação da RPPN Eng.Eliezer Batista). Diário Oficial da União, Seção 1, p. 52, 25/7/2008.

. Patrimônio natural da humanidade, Pantanal guarda biodiversidade única, 2010. Disponível em: https:/www.mma.gov.br/informma/item/6622-patrimonio-natural-da-humanidade-pantanal-guarda-biodiversidade-unica. Acesso em: 26 fev. 2016.

. Portaria n 633 de 25 de outubro de 2019. Aprovação de alteração pontual do Plano de Manejo do Parque Nacional do Pantanal Matogrossense. Diário Oficial da União, 08/11/2019, Edição 217, Seção 1, p. 120. Acesso em: 26 maio 2020.

MPF (Ministério Público Federal). Comunidade do Pantanal recebe autorização para uso sustentável de área tradicional, 2013. Disponível em: www.mpf.mp.br/ms/sala-de-imprensa/ noticias-ms/comunidade-do-pantanal-recebe-autorizacao-para-uso-sustentavel-de-area-tradiconal. Acesso em: 30 mar. 2020.

Decisão histórica assegura à comunidade pantaneira o direito de pescar e coletar iscas para assegurar modo de vida tradicional, 2019. Disponível em: www.mpf.mp.br/ $\mathrm{ms} /$ sala-de-imprensa/noticias-ms/decisao-historica-assegura-a-comunidade-pantaneira-o-direito-de-pescar-e-coletar-iscas-para-assegurar-modo-de-vida-tradicional. Acesso em: 30 jun. 2020.

PEET, R.; ROBBINS, P.; WATTS, M. Global Nature. In: PEET, R.; ROBBINS, P.; WATTS, M. (Orgs.). Global political ecology, p.1-52. Milton Park: Routledge, 2011.

PEPPER, D. A history of environmental thought. Londres: Routledge, 1996.

REDCLIFT, M. Sustainable development: exploring the contradictions. Londres: Methuen, 1987.

SEMA/MS (Secretaria de MeioAmbiente de Mato Grosso do Sul) Deliberação 22 de 8 de junho de 2005. Dispõe sobre reconhecimento de Reserva Particular do Patrimônio Natural da Fundação Ecotrópica. (RPPN Fazenda Rumo ao Oeste), 2005. 
SERNAP. Area natural de manejo integrado San Matias. Santa Cruz de la Sierra: Oficina Central ANMI San Matias, 2018. Disponível em: http://sernap.gob.bo/sanmatias/. Acesso em: 7 maio 2020.

SILVA, J. S. V.; ABDON, M. M. Delimitação do Pantanal Brasileiro e suas sub-regiões. Pesquisa Agropecuária Brasileira, v. 33, número especial, p. 1703-1711, 1998.

SILVA NETO, R. F. Considerações sobre a zona de amortecimento em unidades de conservação federais: da problemática acerca de sua fixação. Revista Jus Navigandi, vol. 17, no 3386, 2012.

SIQUEIRA, A. L. Conflitos socioambientais em comunidades tradicionais da fronteira Brasil-Bolívia e a experiência de implantação do turismo de base sustentável como alternativa de renda na comunidade da Barra do São Lourenço. 2015. Dissertação (Mestrado) - Programa de Pós-Graduação em Estudos Fronteiriços. Universidade Federal de Mato Grosso do Sul, Corumbá.

SIQUEIRA, A. L.; SILVA, A.; SILVA, B. L. P. Áreas protegidas no pantanal: comunidade tradicional da Barra do São Lourenço na fronteira Brasil/Bolívia - região de Corumbá MS. Ra'Ega, v. 45, n. 1, p. 74-90, 2018.

SPU (Secretaria do Patrimônio da União). Portaria no 57 de 7 de abril de 2016 (TAUS de Barra de São Lourenço). Diário Oficial da União. Edição 57, Seção 1, p. 71, 08/04/2016.

- Regularização fundiária na Amazônia Legal. Implicações no patrimônio imobiliário da União. Brasília: Ministério do Planejamento, Desenvolvimento e Gestão, 2017. Disponível em: https://www2.camara.leg.br/atividade-legislativa/comissoes/comissoes-permanentes/ capadr/ audiencias-publicas/audiencias-publicas-2017/audiencia-publica-03-de-outubro-de-2017-mp. Acesso em: 29 abr. 2020.

. Patrimônio da União. Beneficiários - Regularização Fundiária, s/d. Disponível em: https://www.gov.br/economia/pt-br/assuntos/planejamento/gestao/patrimonio-da-uniao/ destinacao-de-imoveis/beneficiarios-regularizacao-fundiaria. Acesso em: 29 abr. 2020.

SYMONS, L. Agricultural geography. Londres: Bell, 1970.

VIEIRA, L. M.; GALDINO, S.; PADOVANI, C. R. Diagnóstico e diretrizes do Plano de Conservação da Bacia do Alto Paraguai para a Bacia do Rio Taquari. In: GALDINO, S.; VIEIRA, L. M.; PELLEGRIN, L.A. (Orgs.). Impactos ambientais e socioeconômicos na bacia do rio Taquari - Pantanal, p. 45-70. Corumbá: EMBRAPA Pantanal, 2006.

WILSON, A. The culture of nature. Londres: Routledge, 1992.

WOLF, E. Europe and the people without history. Berkeley: Univ. of California Press, 1982. 
WOOLCOCK, M. The place of social capital in understanding social and economic outcomes. Isuma Canadian Journal of Policy Research, v. 2, n. 1, p.1-17, 2001.

ZANATA, S. C. S. Comunidade ribeirinha Barra de São Lourenço. 2011. Dissertação (Mestrado) - Programa de Pós-Graduação em Desenvolvimento Local. Universidade Católica Dom Bosco, Campo Grande.

\title{
Agradecimentos
}

Pesquisa apoiada pelo Conselho Nacional de Desenvolvimento Conselho Nacional de Desenvolvimento Científico e Tecnológico - CNPq e com suporte para trabalho de campo da Universidade Federal de Mato Grosso do Sul, campi de Campo Grande e de Corumbá.

\begin{abstract}
${ }^{1}$ Parque Nacional do Pantanal Matogrossense criado pelo Decreto de Lei n ${ }^{\circ} 86.392$ de 24 de setembro de 1981. Reserva Biológica Caracará criada pelo Decreto nº 68.691 de 28 de maio de 1971.

${ }^{2}$ Populações tradicionais são reconhecidas no Brasil pelo Decreto n ${ }^{\circ}$ 6.040/2007 que institui a Política Nacional de Desenvolvimento Sustentável dos Povos e Comunidades Tradicionais.

${ }^{3}$ Vídeo Identidade e Permanência, Ribeirinhos no Pantanal do Paraguai. Registro de depoimentos de ribeirinhos em audiência pública em Barra de São Lourenço em 19 de maio de 2015.

${ }^{4}$ Comunidade na região tem conotação semelhante a como o termo é usado por movimentos sociais e designa povos e comunidades tradicionais no decreto 6.040 de 2007 . Tem conotação locacional e territorial de povos tradicionais no reconhecimento de lugares habitados e de uso de recursos naturais essenciais para reprodução social. Subentende relações territoriais do grupo na sua interação com o uso dos recursos naturais e nas relações interpessoais e sua identidade (CNDH, 2018). Academicamente, comunidade é um conceito mais complexos que exprime conexões de relações interdependentes de grupos sociais de alguma maneira organizados e atuantes em função objetivos coletivos em diferentes escalas (BICALHO, 2009; WOOLCOK, 2001).

${ }^{5} \mathrm{O}$ quadro físico e a paisagem natural do Pantanal não são objeto de estudo deste trabalho. Autores atuantes nessa linha de investigação, a exemplo de alguns deles: Ab'Saber (1939), ANA (2017), Galdino et al. (2006), Jesus e Lima (2003), Macedo et al. (2019), Silva e Abdon (1998).

${ }^{6}$ Criação das RPPN: MMA/IBAMA Portaria ${ }^{\circ} 6$ de fevereiro de 1997 - RPPN Fazenda Estância com 26518 ha e Portaria n 7 de 19 de fevereiro de 1997 - RPPNs Fazendas Acurizal e Fazenda Penha, com 13200 ha e 13100 há respectivamente. MMA/ICMBio Portaria ${ }^{\circ} 51$ de 24 de julho de 2008 RPPN Eng.Eliezer Batista, com 13323,4386 há. SEMA/MS Deliberação nº 22 de 8 de junho de 2005 - RPPN Fazenda Rumo Oeste com 990 ha.

${ }^{7}$ Adapta-se as subdivisões de tipos de subsistência de Symons (1970), considerando a proporcionalidade do total da produção destinada ao consumo e à comercialização, sendo: 1- quase subsistência, $10 \%$ a $25 \%$ da produção comercializada e 2 - semi-subsistência, $25 \%$ a $50 \%$ da produção comercializada.

${ }^{8}$ TAUS é um instrumento de regulação fundiária da Superintendência do Patrimônio da União (SPU) criado pela Portaria de 15 de abril de 2010 que visa, Art.1 $1^{\circ}$ : "Disciplinar a utilização e o aproveitamento dos imóveis da União em favor das comunidades tradicionais, com o objetivo de possibilitar a ordenação do uso racional e sustentável dos recursos naturais disponíveis na orla marítima e fluvial, voltados à subsistência dessa população..." (SPU, 2017).
\end{abstract}

Espaço Aberto, PPGG - UFRJ, Rio de Janeiro, V. 10, N.2, p. 205-235, 2020 